\title{
INVESTIGATION OF HYGROSCOPIC PROPERTIES AND POROSITY OF GLUED REINFORCED SAUSAGE CASINGS
}

\author{
Vyacheslav Onishchenko \\ Department of Meat Technology $y^{l}$ \\ onvm70@gmail.com \\ Andrey Pak \\ Department of power machine building, engineering and physical \\ and mathematical disciplines ${ }^{1}$ \\ a.pak@hduht.edu.ua \\ Andrii Goralchuk \\ Department of food technologies in restaurant industry ${ }^{l}$ \\ abgora@gmail.com
}

Lidiia Shubina ${ }^{2}$

tovaroved1205@gmail.com

Viktoria Bolshakova

Department of Meat Technology ${ }^{l}$

viktbol@gmail.com

Samvel Inzhyyants

Ltd «Chuhuyivskyy myasokombinat»

50 Heroyiv Chornobyl'tsiv str., Kharkiv region, Chuguyiv, Ukraine, 63503

samvel123@gmail.com

Alina Pak ${ }^{2}$

pak.alina1984@gmail.com

Olena Domanova ${ }^{2}$

tovaroved1205@gmail.com

${ }^{1}$ Kharkiv State University of Food Technology and Trade

333 Klochkivska str., Kharkiv, Ukraine, 61051

${ }^{2}$ Department of Marketing, Management and Trade Entrepreneurship

Kharkiv Institute of Trade and Economics

of Kyiv National University of Trade and Economics

8 Otakara Yarosha side str., Kharkiv, Ukraine, 61045

\footnotetext{
Abstract

There is substantiated the topicality of studying hygroscopic properties and porosity of glued reinforced sausage casings of intestinal raw materials. The work aim is to establish storage conditions of glued reinforced sausage casings of intestinal raw materials and their porosity determination. Studies of hygroscopic properties of glued reinforced sausage casings of intestinal raw materials have established a possibility of their long-term storage in a polymer package at a relative humidity no more $60 \ldots 70 \%$. It has been established, that at a relative humidity more $70 \%$, storage is possible only in a steam-tight package. It has been noted, that a storage temperature at that must be selected in the diapason from $0{ }^{\circ} \mathrm{C}$ to $25^{\circ} \mathrm{C}$. It has been established, that the sorption isotherm for a model of a reinforcing seam material, obtained from glued intestinal casings using thermal coagulation, is lower than the one of the glued casing of intestinal raw materials relative to the axis of moisture content. The research result is explained by different porosity of samples. Differential functions of pores distribution by radiuses for studied samples have been obtained, and most probable and average radiuses for them have been calculated. The obtained distribution functions have a similar character and close maximum
} 
positions relative to the axis that the size-free pore radius is put on. They differ by lines width, testifying to the fact that samples differ by relative number of pores of different radiuses. It has been established, that most probable radiuses of pores for the studied samples differ within error, and average radiuses differ more than twice. It has been noted, that just more developed porous structure is a cause of the fact that the sorption isotherm of glued casings is higher relative to the one of a reinforcing seam material model. It has been noted, that at reinforcing protein molecules of the initial raw material change their structure because of thermal coagulation in such a way that the porous composition of the obtained raw material becomes closer to the monodispersed one.

Keywords: glued reinforced sausage casings of intestinal raw materials, reinforcing, sorption isotherms, porosity.

DOI: $10.21303 / 2504-5695.2021 .001632$

\section{Introduction}

Correct choice of casings plays an important role in quality formation and competitiveness improvement of sausage products. Today the wide spectrum of casings of different nature and destination are presented at the market [1]. At that the main destination of sausage casings is protection functions realization [2].

Among the wide list of protection properties, the most important are permeability and firmness [3, 4]. In their turn, permeability and firmness values are closely connected with hygroscopic properties and porosity of a material that casings themselves are made of. They are determined mostly by density of the macromolecules package, content of low-molecular substances, swelling as a result of the water steam influence, activating diffusion [5].

The ability of glued reinforced sausage casings of intestinal raw materials not to change their properties for a long time is mainly determined by their hygroscopic properties that are an ability to emit or to absorb water steam from the external environment. Being in the atmosphere of humid air, glued reinforced sausage casings with water content $7 \ldots 10 \%$ can exchange water with the external environment. If the partial pressure of water steam near the product surface is higher than the one of steam air evaporation (desorption) takes place. The mass and the water content of the sample at that decrease. If the ratio of partial pressures is reverse, sample moistening (sorption) takes place - its mass and water content increase. At that a glued sausage casing of intestinal raw materials is characterized by the balanced water content - the water steam pressure above the surface and the one in atmosphere become even. These processes play an important role at storing such dried products and determine storage conditions and terms. At that it must be noted, that sausage casings are usually stored as salted finished products wet. Storage wet, comparing with storage dry, results in additional expenditures for storage and transportation.

Last time enough attention is paid to the problem of formation of protective properties of artificial sausage casings. Scientific technical solutions for creating artificial flexible films with given properties, allowing to use them for separate groups of sausage products, were obtained [6,7]. As to natural casings with inherent universal technological properties, their rational use is interfered by an essential share of technological spoilage, instability of calibers, high permeability and low firmness values $[8,9]$. These shortcomings may be eliminated using a technology of glued intestinal casings. Due to the possibility to set diverse forms and sizes, to vary necessary numbers of layers, conditions for correcting protective properties in wide limits form [10]. Rational parameters of local thermal coagulation have been determined that allows to increase the firmness of glued intestinal casings [11]. But the porous structure and hygroscopic properties of glued intestinal casings as parameters, determining their protective properties and storage conditions, have not been studied yet. Thus, it is an important task to study hygroscopic properties and porosity of glued reinforced natural sausage casings.

The work aim is to establish storage conditions of glued reinforced sausage casings of intestinal raw materials and their porosity determination.

\section{Materials and Methods}

Glued reinforced sausage casings of intestinal raw materials and their fragments, reinforced using local thermal coagulation, were studied [11]. The samples were prepared by the following way: finished products of pork stomachs were released from salt, washed and kept in water. Then the prepared raw materials were cut, obtained ribbons were put on the cylindric form and dried at 
temperature $35 \ldots 39^{\circ} \mathrm{C}$ to the water content no more $10 \%$ [11]. Square samples with size $50 \times 50 \mathrm{~mm}$ were cut of the glued casings, obtained in such a way from intestinal raw materials. It is necessary to note, that reinforcing seam functions in glued reinforced sausage casings are realized by a part of the same raw material, subjected to thermal coagulation. Modeling of this part of glued reinforced sausage casings as conducted in the following way: the initial raw material samples (glued casings of intestinal raw materials) with size $50 \times 50 \mathrm{~mm}$ were squeezed between heating surfaces with temperature $170{ }^{\circ} \mathrm{C}$. Sizes of the heating surfaces, thermal capacity and thermal conductivity of materials that they were produced from, were much more, comparing with sizes and thermal properties of initial material samples. They were kept between the heating surfaces during $5 \mathrm{~s}$. Such samples are a model of the reinforcing seam material, obtained using thermal coagulation.

For studying sorption and determining the balanced water content of glued reinforced sausage casings of intestinal raw materials and their fragments, reinforced by local thermal coagulation, the tensometric method was used. The studied sample was placed in a dessicator with the fixed value of relative air humidity $\varphi$ in the diapason from 10 to $90 \%$. All dessicators were kept at the constant temperature of the external environment during the measurements $\left(20 \ldots 23^{\circ} \mathrm{C}\right)$. The duration of product's stay in the dessicator was determined by attaining the constant mass. The research result is sorption isotherms of the samples that are the dependence of the sample water content on relative humidity in the dessicator.

The approximation of the experimental data, obtained by the tensometric method for constructing the sorption isotherm, was conducted by the function as [12]:

$$
\phi=\frac{w^{A_{3}}}{A_{1}+A_{2} w^{A_{3}}},
$$

where $A_{1}, A_{2}, A_{3}$ - approximation coefficients; $w$ - balanced water content.

The use of such approximation function gives a possibility to get a differential function of pores distribution by radiuses $f_{n}\left(R^{*}\right)$.

The differential function of pores distribution is determined as [12]:

$$
f_{n}\left(R^{*}\right)=\frac{1}{\sqrt{2 \pi} \sigma_{R} R^{*}} \exp \left(-\frac{\left(\ln \left(R^{*}\right)-m_{R}\right)^{2}}{2 \sigma_{R}^{2}}\right),
$$

where $m_{R}$ ana $\sigma_{R}$ - parameters of logarithmically normal distribution; $R^{*}-$ size-free pore radius:

$$
R^{*}=\left(R-d_{0}\right) / d_{0}
$$

where $R$ - pore radius, $\mathrm{m} ; d_{0}=0.3 \cdot 10^{-9} \mathrm{~m}$ - water molecule radius.

Parameters of logarithmically normal distribution are calculated by formulas [12]:

$$
\begin{gathered}
m_{R}=\left(\frac{A_{2}}{0.433}\right)^{1.247}, \\
\sigma_{R}=-\frac{\ln \left(6.12 A_{1}\right)}{0.625}\left(\frac{A_{3}-0.957}{0.223}\right)^{-0.6} .
\end{gathered}
$$

The average distribution is calculated by the obtained distribution functions:

$$
\bar{R}=d_{0}\left[1+\exp \left(m_{R}+\sigma_{R}^{2} / 2\right)\right] .
$$

And the most probable pore radius (distribution center)

$$
R_{m}=d_{0}\left[1+\exp \left(m_{R}-\sigma_{R}^{2}\right)\right]
$$


The sorption isotherms and differential functions of pores distribution by radiuses were determined for the samples of glued casings of intestinal raw materials and for the ones that are a model of the reinforcing seam material, obtained using thermal coagulation [11].

\section{Research results}

The sorption isotherms of the samples of glued casings of intestinal raw materials and of the ones that are a model of the reinforcing seam material, obtained using thermal coagulation are presented on Fig. 1.

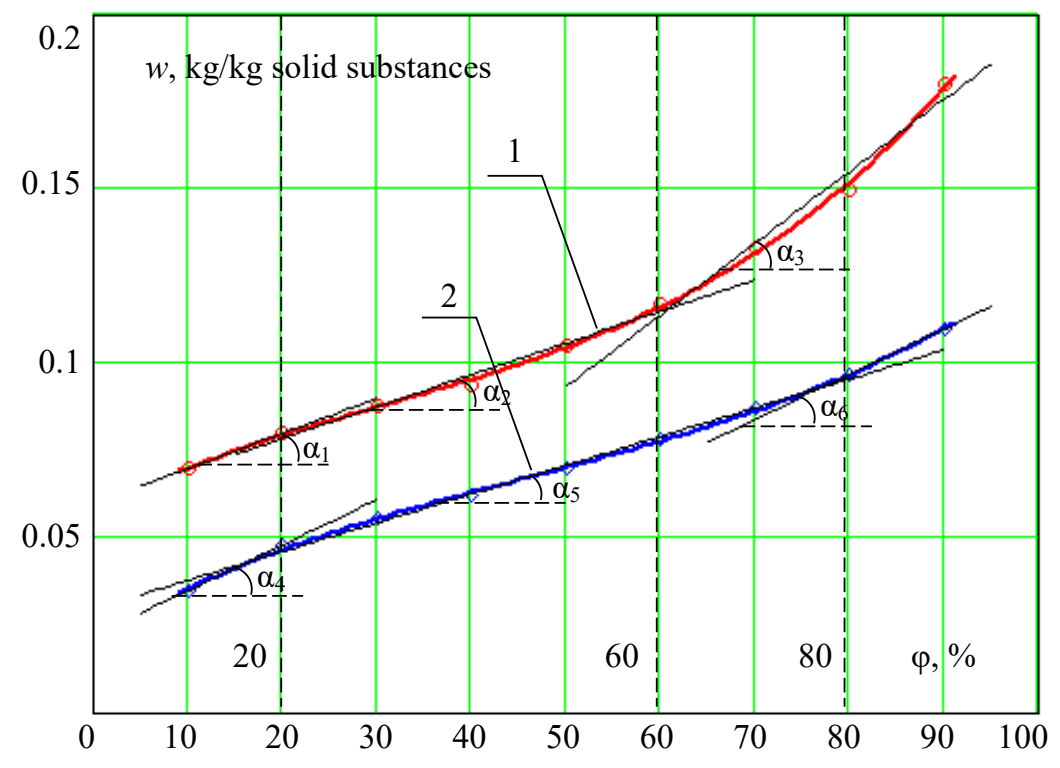

Fig. 1. Isotherms of sorption: 1 - glued casings of intestinal raw materials; 2 - model of the reinforcing seam material, obtained using thermal coagulation

Glued casings of intestinal raw materials are in the area of monomolecular and polymolecular sorption in the relative humidity diapason from 10 to $60 \%$. At that the casings are in the area of monomolecular sorption at humidity from 10 to $20 \%$ that can be seen from the constant slope angle $\left(\alpha_{1}\right)$ of the dependence to the $X$ axis. At further relative humidity increase the slope angle increases $\left(\alpha_{2}\right)$ - the sample is in the area of polymolecular sorption. The relative humidity diapason, corresponding to poymolecular sorption of the samples of glued casings of intestinal raw materials, is from 20 to $60 \%$.

At further humidity increase water absorption by microcapillaries and swelling of the samples take place. It is testified by the slope angle increase to the value $\alpha_{3}$. But the type of isotherms has no brightly expressed asymptote of the parallel water content axis. Further moistening of such samples is possible only at direct contact with a liquid. The obtained result demonstrates the possibility of their long-term storage in a polymer package at the relative humidity no more $60 \ldots 70 \%$, and at the relative humidity more $70 \%$, storage is possible only in a steam-tight package. Based on the conducted study, it is recommended to store glued casings of intestinal raw materials at the temperature from $0{ }^{\circ} \mathrm{C}$ to $25^{\circ} \mathrm{C}$ at the relative humidity no more $70 \%$.

The isotherm type is analogous for the samples that are a reinforcing seam material model. It differs by the relative humidity diapason, corresponding to polymolecular sorption of the samples. The diapason for the reinforcing seam material model is from 20 to $80 \%$ (slope angle $\alpha_{5}$ ). So, there is a possibility to save such sample at the relative humidity from 80 to $90 \%$, and their further moistening is possible only at direct contact with water.

It is necessary to note, that the sorption isotherm of glued casings of intestinal raw materials is higher than the one of the reinforcing seam material model relative to the water content axis. The obtained result is explained by different porosity of the samples. 
Fig. 2 presents the differential functions of pores distribution by radiuses for the studied samples, obtained by the method, described in p. 2 [12]. The independent variable of the differential distribution function $f_{n}\left(R^{*}\right)$ is the size-free radius $\mathrm{R}^{*}$, calculated by formula (3).

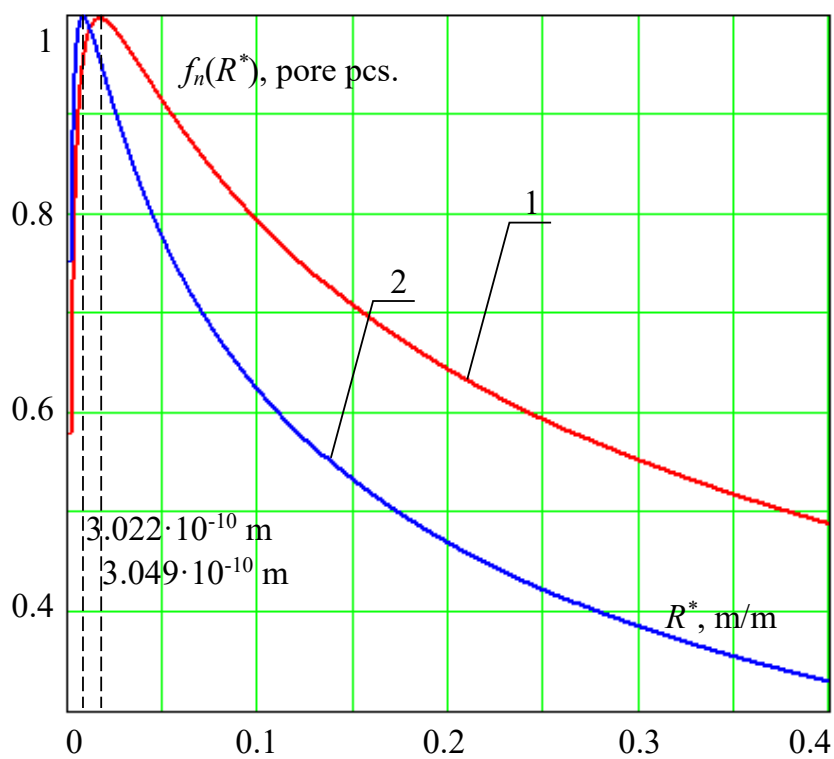

Fig.2. Differential functions of pores by radiuses: 1 - glued casings of intestinal raw materials; 2 - model of the reinforcing seam material, obtained using thermal coagulation

The obtained distribution functions have the similar character and close maximum positions relative to the axis that the size-free pore radius is put on. They differ by lines width, testifying to the fact that the samples differ by relative number of pores of different radiuses.

The average and most probable radiuses for the studied samples, calculated by formulas (6) and (7) respectively, are:

- for glued casings of intestinal raw materials: $\bar{R}=2.284 \cdot 10^{-7} \mathrm{~m} ; R_{m}=3.049 \cdot 10^{-10} \mathrm{~m}$;

- for the model of the reinforcing seam material, obtained using thermal coagulation: $\bar{R}=1.014 \cdot 10^{-7} \mathrm{~m} ; R_{m}=3.022 \cdot 10^{-10} \mathrm{~m}$.

The most probable radiuses of pores for the studied samples differ within error. But the average radiuses differ more than twice. It is also testified by the wider line of the function of pores distribution by radiuses for glued casings. Just more developed porous structure is a cause of the fact that the sorption isotherm of glued casings is higher relative to the one of the reinforcing seam material model. That is at reinforcing protein molecules of the initial raw material change their structure because of thermal coagulation in such a way that the porous composition of the obtained raw material becomes closer to the monodispersed one.

\section{Conclusions}

The studies of hygroscopic properties of glued reinforced sausage casings of intestinal raw materials have established a possibility of their long-term storage in a polymer package at the relative humidity no more $60 \ldots 70 \%$. It has been established, that at the relative humidity more $70 \%$ storage is possible only in a steam-tight package. It has been noted, that the storage temperature at that must be selected in the diapason from $0{ }^{\circ} \mathrm{C}$ to $25^{\circ} \mathrm{C}$.

It has been established, that the sorption isotherm for the model of the reinforcing seam material, obtained from glued intestinal casings using thermal coagulation, is lower relative to the axis of moisture content than the one of a glued casing of intestinal raw materials. It is caused by more developed porous structure that is proved by the studies of porosity of samples. It is noted, that at reinforcing protein molecules of the initial raw material change their structure because of thermal 
coagulation in such a way that the porous composition of the obtained raw material becomes closer to the monodispersed one. Just this property of the reinforcing seam material, obtained of glued intestinal casings by thermal coagulation, determines the ability of the casing to absorb water at sausages production that is a promising direction of further studies.

\section{References}

[1] Suurs, P., Barbut, S. (2020). Collagen use for co-extruded sausage casings - A review. Trends in Food Science \& Technology, 102, 91-101. doi: https://doi.org/10.1016/j.tifs.2020.06.011

[2] Savic, Z., Savic, I. (2016). Sausage Casings. Wien: Victus International GmbH, 612. Available at: https://www.linkedin.com/ pulse/new-publication-book-sausage-casings-zoran-savic?trk=portfolio_article-card_title

[3] Mykhailov, V., Onishchenko, V., Ostroverch, I., Bolshakova, V., Skurihina, L. (2016). Permeability evaluation of natural sausage casings. Technology Audit and Production Reserves, 6 (3 (32)), 22-27. doi: https://doi.org/10.15587/2312-8372.2016.85584

[4] Wijnker, J. J. (2009). Aspects of quality assurance in processing natural sausage casings. Ridderkerk: Ridderprint, 114. Available at: https://www.academia.edu/22843702/Aspects_of_quality_assurance_in_processing_natural_sausage_casings

[5] Levanichev, V. V., Larchenkova, T. I., Bakalo, L. G., Tereshchenko, T. M. (2003). Issledovanie bar'ernyh svoystv poliamidnyh obolochek. Myasnoe delo, 1, 10-11.

[6] Lang, B.-A., Effenberger, G. (2009). Kolbasnye obolochki. Natural'nye, iskusstvennye, sinteticheskie. Sankt-Peterburg: Professiya, 256. Available at: http://www.tnu.in.ua/study/books/entry-2022454.html

[7] Patiño, J. H., Henríquez, L. E., Restrepo, D., Mendoza, M. P., Lantero, M. I., García, M. A. (2014). Evaluation of polyamide composite casings with silver-zinc crystals for sausages packaging. Food Packaging and Shelf Life, 1 (1), 3-9. doi: https://doi.org/ 10.1016/j.fpsl.2013.09.001

[8] Çağlar, A., Bor, Y., Tomar, O., Beykaya, M., Gök, V. (2018). Mechanical and Microbiological Properties of Natural Casings Using in Meat Products. Kafkas Universitesi veteriner fakultesi Dergisi Journal, 24 (3), 327-334. doi: https://doi.org/10.9775/ kvfd.2017.18885

[9] Sidorova, E. V., Sus', I. V. (2011). Kishechnoe proizvodstvo. Nauka i praktika. Moscow: Editorial servis, 228. Available at: https://www.elibrary.ru/item.asp?id=21374429

[10] Uretja, S. N., Lavrinenko, I. V., Sidorova, E. V., Nosova, T. I., Denisova, O. I. (2005). Pat. No. 2326540 RU. Method of pork rounds coating production. No. 2005120659/13; declareted: 04.07.2005; published: 20.06.2008, Bul. No. 17. Available at: http:// www.freepatent.ru/images/patents/139/2326540/patent-2326540.pdf

[11] Mykhailov, V., Onyshchenko, V., Pak, A., Pak, A. (2020). Determination of rational temperature and thermal coagulation duration of glued natural casings. Prohresyvni tekhnika ta tekhnolohiyi kharchovykh vyrobnytstv restorannoho hospodarstva i torhivli, 2 (32), 221-232. Available at: http://elib.hduht.edu.ua/bitstream/123456789/5954/1/20.pdf

[12] Potapov, V. O. (2005). Strukturno-enerhetychnyi metod analizu izoterm sorbtsiyi-desorbtsiyi kharchovoi syrovyny. Prohresyvni tekhnika ta tekhnolohiyi kharchovykh vyrobnytstv restorannoho hospodarstva i torhivli, 1, 313-322.

Received date 02.12.2020

Accepted date 26.01.2021

Published date 29.01.2021
(C) The Author(s) 2021

This is an open access article under the CC BY license (http://creativecommons.org/licenses/by/4.0). 